\title{
Meta
}

Journal des traducteurs

Translators' Journal

\section{WARREN, Rosanna (Ed.) (1989): The Art of Translation: Voices from the Field, Boston: Northeastern University Press, 290 p.}

\section{Brenda M. Hosington}

Volume 36, numéro 2-3, juin 1991

URI : https://id.erudit.org/iderudit/003132ar

DOI : https://doi.org/10.7202/003132ar

Aller au sommaire du numéro

Éditeur(s)

Les Presses de l'Université de Montréal

ISSN

0026-0452 (imprimé)

1492-1421 (numérique)

Découvrir la revue

Citer ce compte rendu

Hosington, B. M. (1991). Compte rendu de [WARREN, Rosanna (Ed.) (1989): The Art of Translation: Voices from the Field, Boston: Northeastern University Press, 290 p.] Meta, 36(2-3), 514-517. https://doi.org/10.7202/003132ar

Ce document est protégé par la loi sur le droit d'auteur. L'utilisation des services d'Érudit (y compris la reproduction) est assujettie à sa politique d'utilisation que vous pouvez consulter en ligne.

https://apropos.erudit.org/fr/usagers/politique-dutilisation/
Cet article est diffusé et préservé par Érudit.

Érudit est un consortium interuniversitaire sans but lucratif composé de l’Université de Montréal, l'Université Laval et l'Université du Québec à Montréal. Il a pour mission la promotion et la valorisation de la recherche. https://www.erudit.org/fr/ 
WARREN, Rosanna (Ed.) (1989): The Art of Translation: Voices from the Field, Boston: Northeastern University Press, 290 p.

In this important collection of essays, which represent the lectures given over the past decade in the Translation Seminars at Boston University, we are presented with a variety of viewpoints from specialists who are academics, writers, and translators, and sometimes all three. Following in the tradition of Arrowsmith's and Chattuck's 1961 Craft and Context of Translation, it offers a state of the art view of translation. And how that art has changed in the twenty-eight-year interval! The various essays bear witness to the revolution in linguistics, philosophy and literary theory that has touched translation theory and practice. The strong presence of Walter Benjamin is seen in many of the pieces, in their celebration of "otherness" and the inevitable "resistance" (on linguistic, historical, social and political levels) of original to translated text. Further strengths and merits of this collection are twofold. Firstly, the range of types of translation represented shows how linguistic, literary and anthropological concerns interlap and overlap; unlike many similar collections, this one dœs not accord literary discourse sole place. Secondly, the contributions come, not from theorists or literary critics per se (although of necessity literary translators are literary critics too), but from published translators; they thus bridge the gap that only too often yawns between theorist and practiciner. These translators, however, can and do discuss actual problems of translation within a context of theoretical discourse. Perhaps this marks the greatest difference between the present volume and The Craft and Context of Translation, a difference that to this reviewer's mind, at least, reflects how far we have gone in raising the subject of translation to new levels of literary, linguistic and philosophical enquiry.

The contributions are divided into five sections. The criteria for inclusion in one or another section sometimes appear rather arbitrary, while the significance of one or two of the section headings is not self-evident. The first part, rather puzzlingly called "Testimonies" (aren't all the essays testimonies, as the book's sub-title suggests?) assembles six articles. Seamus Heaney's "Earning a Rhyme: Notes on Translating Buile Suibhne," Parker Po-Fei Huang's "On the Translation of Chinese Potry," and A.K. Ramanujan's "On Translating a Tamil Pœm" all discuss, with varying degrees of success, the practical problems of potic translation. Ramanujan's is by far the most clearly presented and perceptive. Its list of factors that make translating a pœm possible includes mimicry, the subject of Christopher Middleton's "Translation as a Species of Mime." If rather anecdotal, this essay nevertheless presents some challenging ideas on translating as an act, not of imitation (as has traditionally been suggested), but of mime, which "actualizes a desire for union with the other." Both remaining essays in this section deal with Spanish 
literature and both reflect certain of Bakhtin's ideas on the novel. Agnes Moncy Gullon's "Fortunata and Jacinta: A Polyphonic Novel" is a little muddled in the first part, which seeks to discuss more theoretical concerns, but improves in the second with analyses of actual passages from Gullon's translation of the work. However, overall it is disappointing and at times written in a rather naïve style. Suzanne Jill Levine's essay on Manuel Puig, "From Little Painted Lips to Heartbreak Tango," is on the other hand a model for its genre, a blend of practical concerns with literary and translation theory, well presented and authoritatively argued. Taking Borges' "Pierre Menard" as a point of departure, then moving briefly through sections on translation as subversion, Levine comes to a discussion of a specific translation problem posed by Puig's Boquitas pintadas: how to render the tango lyrics. From her struggle with the culture-bound lyrics, she comes to see the translator as bricoleur, in the Lévi-Straussian sense; like a novelist, he or she is both artist and mediator between text and reader, seeking to "(re)unite signs with meanings."

The second section presents twin essays on translating drama. Rightfully arguing in "Phaedra Britannica" that a play should not become a mere "vehicle" for a performer, Tony Harrison proposes a "social structure which makes the tensions and polarities of the play significant again. To make the roles (...) meaningful again. To grasp the play entire." This he claims to have done in transposing Racine's Phèdre to nineteenth-century colonial India. Both the inner psychological and the outer political dynamics can be successfully expressed by the way the British perceived and ruled the continent. Moreover, he contends, the anglo-saxon audience can more easily identify with colonial India than with the world of classical French theatre. Harrison's defence of his total "subversion" of Racine's text is persuasive. But as the proof of the pudding is in the eating, so the proof of a translated play is in the performing. Critics' views were mixed, as might be expected. On paper, however, Harrison's ideas work and his essay is both cogent and illuminating. Michael Ewans, in "Aischylos: For Actors, in the Round," discusses not a classical theme but a classical dramatist and the problems that arise in translating his plays for performance today. Ewans, like others, argues for texts that are both accurate (textually) and actable (the words can be said and sung). Most modern translations are one or the other but rarely both, either because they do not take into account that Aischylos wrote for open-air theatre in the round, or because the translator did not have a thorough knowledge of Greek. (Here Ewans touches on a sore point. Increasingly of late, London stages have been host to "translations" written by playwrights armed only with a crib, some directing experience and lots of chutzpah.) Ewans' own translation is based on what he sees as essential in theatre translation: the vision of the scene as a whole and how it works on stage, and the interaction of written script, the act of verbal translation, with all the other complementary elements of the play. Again, the essay is persuasive, but we have only its author's word as a proof of the translation's success as theatre. However, both Harrison and Ewans argue convincingly for new approaches in theatre translation, and this makes an important contribution in a field that is still wocfully under-represented in works of literary translation theory.

In the two sections entitled "Anthropology" and "History," the essays deal specifically with the problem of translating texts from other cultures and times. In his excellent "Language, Politics, and Translation: Colonial Discourse and Classic Nahuatl in New Spain," J. Jorge Klor de Alwa analyses, in Foucaultian vein, the ideological devices that permit elements from one discursive formation (or register) to become part of another in order to support arguments on behalf of colonial desires. Literary translation, like language in general, encodes power relations; thus translation from the classical Nahuatle of sixteenth-century Mexico becomes a powerful tool for Spanish claims to sovereignty in 
New Spain. De Alwa's observations on the translation of oral literature are of particuliar interest, as are his comments on "otherness" and colonial discourse. Frederick Ahl's and Rosanna Warren's contributions deal with the historical "otherness" of classical pœtry. They both map the developments of a classical text through various translations. Ahl's "The Classical Hero in Irish Metamorphosis" uses Middle Irish versions of Statius' Thebaid, Vergil's Aeneid, and Lucan's Pharsalia, both to give an overview of these early translations per se, and to provide a "more general insight into the ways in which societies (...) translate works from earlier or parallel cultures into their own languages." As Ahl rightly says, each succeeding wave of translators imposes, either consciously or unconsciously, the values of its own culture on the translated text. The final section is a fine illustration of how an earlier work (here the Odyssey) can become a story in its own right: by assimilating the original completely, it too, like translation in its generally accepted sense, functions as metamorphosis, breathing new life into an old text. Warren suggests a similar process in "Sappho: Translation as Elegy," although she goes beyond Ahl, choosing to describe translation in metaphors of death, resurrection and consolation and taking as its model the literary genre of elegy. The idea is original, imaginative and apt. Taking Sappho's "Phainetai moi" as a point of departure, Warren traces the development of Sapphic pœtry through Catullus, Baudelaire and Swinburne, building an "elegiac genealogy"; translation not only serves to form a "family tree" of texts but also to console, in true elegiac fashion, by keeping pœtry alive. It is the promise of tomorrow's text, or in the words of Milton's Lycidas, of "fresh woods and pastures new."

In the remaining section, three essays are theory-oriented while the fourth and final one is a plea for reassessing the importance of translation in the history of English literature. Charles Tomlinson, in "The Presence of Translation: A View of English Pœtry," argues that Chaucer's influence on English pœtry both up to and including Dryden (and even after) constitutes example after example of inter-lingual translation, while Chaucer was himself a translateur in both the narrower and larger senses of the word. This, however, is not made clear to students. Nor is the importance of translation in the works of Marlowe, Golding, Dryden or Pope. It is an argument with which one cannot but concur; however it might have been expressed in a less rambling manner. In all three theory-oriented essays, Walter Benjamin looms large. Rosemary Waldrop challenges Benjamin's idea of the unit of translation as word, line or sentence, preferring to co-opt for translation Godamer's term "third dimension"; this is the "unsaid" or "space" that is left for the utterance but can be prepared for by "reading around" the text in both source and target languages and cultures. Nevertheless, like Benjamin, Waldrop believes that translation in its ideal state can suggest the lost beauty of the original, can be a "transluciferation" which "dœs not cover the original, dœs not block the light." Richard Sieburth's "The Guest: Second Thoughts on Translating Hölderlin" applies Benjamin's twin conceptions of space in language and of translation as a part of the ongoing Nachleben of the original rather than imitation, reproduction or minesis, to his own translation of Hölderlin's late Hymns and Fragments. Unlike Waldrop and Sieburth, Denis Donoghue is concerned with applying translation theory to someone else's translating practices: Kinsella's English translation of a seventeenth-century anonymous love pœm written in Irish. From accusing Kinsella of "always sounding like himself" despite his claims of fidelity to his original, Donoghue passes to Benjamin's and Paul de Man's description of the relationship between translation and original. For the former, it is one of kinship rather than imitation or similarity; for the latter, this refusal to imitate places a translation in ironic relation to its original, casting upon it the "shadow of death." Donoghue provides a needed corrective to these gloomy views of translation: in practice, translators toil on, aware of the inevitable failure, but continuing to "live among words in 
the conviction of a more accommodating possibility." It is a pity that the editor did not give Donoghue the final say in this most significant and timely collection of "voices from the field"; his essay would have provided a fitting and reassuring sense of "closure".

BRENDA M. HOSINGTON 